\title{
Neuronal and Non-Neuronal Collapsin-1 Binding Sites in Developing Chick Are Distinct from Other Semaphorin Binding Sites
}

\author{
Takuya Takahashi, ${ }^{1,2}$ Fumio Nakamura, ${ }^{1}$ and Stephen M. Strittmatter ${ }^{1,3}$ \\ Departments of ${ }^{1}$ Neurology, ${ }^{2}$ Biology, and ${ }^{3}$ Neurobiology, Yale University, New Haven, Connecticut 06520
}

The collapsin and semaphorin family of extracellular proteins contributes to axonal path finding by repulsing axons and collapsing growth cones. To explore the mechanism of collapsin-1 action, we expressed and purified a truncated collapsin-1-alkaline phosphatase fusion protein (CAP-4). This protein retains biological activity as a DRG growth cone collapsing agent and saturably binds to DRG neurons with low nanomolar affinity. Specific CAP-4 binding sites are present on DRG neurons, sympathetic neurons, and motoneurons, but not on retinal, cortical, or brainstem neurons. Outside the nervous system, high levels of CAP-4 binding sites are present in the mesenchyme surrounding major blood vessels and developing bone and in lung. These sites provide a substrate for the collapsin-1-dependent patterning of non-neuronal tissues perturbed in sema III (-/-) mice. The staining patterns for mouse semaphorin D/III and chick collapsin-1 fusion proteins are indistinguishable from one another but quite separate from that for semaphorin B and $\mathrm{M}$-semaphorin $\mathrm{F}$ fusion proteins. These data imply that a family of high-affinity semaphorin binding sites similar in complexity to the semaphorin ligand family exists.

Key words: collapsin; semaphorin; growth cone collapse; dorsal root ganglion; sympathetic neuron; alkaline phosphatase
The extreme precision of axon pathfinding during neural development depends on both attractive and repulsive guidance signals (for review, see Keynes and Cook, 1995; Tessier-Lavigne and Goodman, 1996). Chick collapsin-1 was isolated as a growth cone collapse factor for sensory neurons (Luo et al., 1993) and is capable of guiding developing axons away from certain territories by a repulsive mechanism. Insect semaphorin I (initially termed fasciclin IV) was identified as the antigen recognized by an axon tract-specific antibody (Kolodkin et al., 1992). Other members of the collapsin and semaphorin family have primarily been identified by nucleic acid sequence homology (Luo et al., 1995; Püschel et al., 1995; for review, see Dodd and Schuchardt, 1995; Kolodkin, 1996; Püschel, 1996). Whereas some semaphorins such as collapsin-1 and its murine homolog semaphorin D/III are secreted proteins, other semaphorins such as semaphorin $\mathrm{B}, \mathrm{C}$, $\mathrm{M}-\mathrm{F}$, and M-G/CD100 are associated with the cell surface via a transmembrane hydrophobic sequence near the $\mathrm{C}$ terminal (Inagaki et al., 1995; Püschel et al., 1995; Furuyama et al., 1996; Hall et al., 1996). Whether family members other than collapsin-1 and semaphorin D/III are repulsive for growing axons is not known.

Several studies have demonstrated that regulation of axonal extension by these proteins contributes to nervous system formation in vivo. Perturbation of grasshopper semaphorin I alters axon trajectory in the limb bud (Kolodkin et al., 1992). Motoneurons

\footnotetext{
Received June 13, 1997; revised Sept. 2, 1997; accepted Sept. 11, 1997.

This work was supported by grants to S.M.S. from the National Institutes of Health and to S.M.S. and F.N. from the Spinal Cord Research Fund of the Paralyzed Veterans of America. S.M.S. is a John Merck Scholar in the Biology of Developmental Disorders in Children. We thank A. W. Püschel for semaphorin B and D clones, S. Inagaki for M-semaphorin F clone, M. Kitagawa for HEK293T cells, L.-H Wang and P. Strittmatter for helpful discussions, H. Fryer for assistance with motoneuron cultures, and Z. Jin for assistance with DRG cultures.

T.T. and F.N. contributed equally to this work.

Correspondence should be addressed to Dr. Stephen Strittmatter, Department of Neurology, Yale University School of Medicine, P.O. Box 208018, 333 Cedar Street, New Haven, CT 06520.

Copyright (C) 1997 Society for Neuroscience $\quad 0270-6474 / 97 / 179183-11 \$ 05.00 / 0$
}

are sensitive to semaphorin D/III in vitro (Varela-Echavarria et al., 1997), and ectopic expression of semaphorin II in selected Drosophila muscles alters motoneuron innervation (Matthes et al., 1995). The relative insensitivity of the neurotrophin-3 (NT3)-dependent dorsal root ganglion (DRG) subpopulation to collapsin-1 or its murine homolog semaphorin D/III, coupled with the ventral spinal cord expression of the protein, has suggested that this semaphorin participates in the patterning of the central projections of some sensory neurons (Messersmith et al., 1995; Shepherd et al., 1997). Analysis of mice lacking semaphorin D/III has confirmed that certain DRG neurons project aberrantly in the spinal cord (Behar et al., 1996).

Semaphorins are expressed in a number of non-neuronal tissues (Püschel et al., 1995; Giger et al., 1996). Mice lacking semaphorin D/III develop an enlarged cardiac right ventricle and malformation of the skeleton (Behar et al., 1996). This may be attributable to loss of the normal effects of semaphorin D/III protein expression in the lung and in the mesenchyme surrounding developing bone (Giger et al., 1996). A role for semaphorins in immune function is suggested by the expression of $\mathrm{M}$ semaphorin G (CD100) in T lymphocytes (Furuyama et al., 1996; Hall et al., 1996; Herold et al., 1996) and perhaps by the expression of semaphorin-like molecules by several viruses (Kolodkin et al., 1993). Several small cell lung cancer cell lines exhibit homozygous deletion in chromosome region 3 p21.3 where semaphorin A and human semaphorin IV are located (Roche et al., 1996; Sekido et al., 1996; Xiang et al., 1996). This raises the possibility that some members of the semaphorin and collapsin family function as tumor suppressors.

The molecular mechanism of collapsin and semaphorin action remains poorly defined. We have provided evidence that a pertussis toxin-sensitive heterotrimeric GTP-binding protein mediates collapsin-1-induced growth cone collapse (Igarashi et al., 1993; Goshima et al., 1995; Jin and Strittmatter, 1997). The intracellular protein CRMP (TOAD and ULIP) seems to be 
required for collapsin-1 signaling, but its mechanism of action is unclear (Goshima et al., 1995; Minturn et al., 1995; Byk et al., 1996). Downstream signaling events in collapsin-1 action include activation of rac1 and depolymerization of growth cone actin filaments (Fan et al., 1993; Jin and Strittmatter, 1997).

Despite these hints about the intracellular cascades activated by collapsin-1, there is no information concerning the nature of a high-affinity cell surface binding site for any of the collapsins and semaphorins. In this study we have developed a collapsin-1alkaline phosphatase fusion protein (CAP) to visualize cell surface collapsin-1 binding sites. Saturable, high-affinity binding is detected on selective neuronal populations and extraneural tissues. The localization of binding sites for different semaphorin family members is unique, implying a family of semaphorin receptors of complexity similar to that of the ligand family.

\section{MATERIALS AND METHODS}

Construction of expression vectors for collapsin-1-His ${ }_{6}$ and collapsin-alkaline phosphatase fusion proteins. The $\mathrm{C}$ terminal of the chick collapsin-1 coding region was amplified by PCR using the $5^{\prime}$-EcoRI primer (CAATGGATGAATTCTGTGAGCAGGT) and the $3^{\prime}$-(His) 6 primer (GGACTCTAGAGGTCATGCTGCATGATGATGATGATGATGGACACTCCGTGGTGCCCT). pcDNA-collapsin-1 was used as the DNA template for the reaction (Luo et al., 1993; Goshima et al., 1995). The amplified fragment was digested with EcoRI and $X b a \mathrm{I}$ and cloned into the NotI-XbaI sites of pcDNA1 together with the NotI-EcoRI fragment (nucleotides 130-2160) of collapsin-1 cDNA to create pc-collapsin-1-His 6 .

The entire alkaline phosphatase (AP) coding region of pSEAP (Clontech, Cambridge, UK) was amplified by PCR with the $5^{\prime}$-AP1 primer (CCAGTCTAGAATGCTGCTGCTGCTGCTGCTGCTGGGCCTGAGGCTACAG) and the $3^{\prime}$-AP-His ${ }_{6}$ primer (CCAGAGATCTTCATGCTGCATGATGATGATGATGATGACCCGGGTGCGCGGCGTCGGT), polished with PfuI, and ligated in the EcoRV of pcDNA1 site. This pcAP vector was used for (His) ${ }_{6}$-tagged AP expression. In addition, pcDNA and AP vectors with $X b a \mathrm{I}$ or EcoRI cloning sites were generated. An AP3 fragment (52-1517) lacking the signal sequence was amplified with the 5'-AP3-XbaI primer (CCAGTCTAGAATCATCCCAGTTGAGGAGGAGAACCCGGACTTCTGG) and the 3'-AP-His(6) primer. This fragment was polished with PfuI and blunt-end ligated to the $X b a$ I site of pcDNA1. This pcAP3 plasmid was used for the construction of pcCAP-3, semaphorin B-alkaline phosphatase (sema B$\mathrm{AP}$ ), semaphorin $\mathrm{D}$-alkaline phosphatase (sema D-AP), and $\mathrm{M}$ semaphorin $\mathrm{F}$-alkaline phosphatase (M-sema F-AP). These fusion protein vectors encode a Ser-Arg between the semaphorin and the alkaline phosphatase moieties. An AP4 fragment (52-1517) was amplified with the 5'-AP4-EcoRI primer (CCGAATTCATCATCCCAGTTGAGGAGGAGAACCCGGACTTCTGG) and the $3^{\prime}$-AP-His ${ }_{6}$ primer, polished with PfuI, and digested with EcoRI. This fragment was inserted at the EcoRI-EcoRV sites of pcDNA1 to create pcAP4. The CAP-4 construct created from pcAP4 contains a Glu-Phe linker between protein domains.

The collapsin-1 coding region was amplified from pcDNA-collapsin-1 with the T7 primer (TAATACGACTCACTATAGGG) and the $3^{\prime}-\mathrm{XbaI}$ primer (CCAGTCTAGAGACACTCCGTGGTGCCCTCTC), digested with $N o t \mathrm{I}$ and $X b a \mathrm{I}$, and ligated into Not $\mathrm{I}-\mathrm{Xba \textrm {I }}$ sites of pcAP3 to create pcCAP-3. The EcoRI fragment (-7-2160) of pcCAP-3 was inserted at the EcoRI site of pcAP4 to create pcCAP-4. The extracellular domain of semaphorin B (-7-2108) was amplified by PCR from pBluescript SKsemaphorin B (Püschel et al., 1995) with the 5'-T3 primer (AATTAACCCTCACTAAAGGG) and the $3^{\prime}$-XbaI primer (GATTCTAGAGGGCCAGTAGGACCGCTGGGCATC), digested with $X b a \mathrm{I}$, and ligated into the $X b a \mathrm{I}$ site of pcAP3 to create sema B-AP. The pBKCMV-SemD (Püschel et al., 1995) clone lacks the initial 270 nucleotides of the coding region. The missing sequence was amplified by PCR with embryonic day 17 (E17) mouse embryo cDNA (Clontech) as template and ligated into the TA cloning vector (Invitrogen, San Diego, CA) to create TA-5'-semaphorin D. The $3^{\prime}$ coding region from $\mathrm{pBK}-\mathrm{CMV}$ SemD was inserted into TA-5'-semaphorin D using the EcoRV site at position 325 to create the full-length clone TA-semaphorin D. The truncated form of semaphorin D lacking $\mathrm{C}$-terminal basic rich residues $(-8-2270)$ was amplified by PCR from TA-semaphorin D with the 5'-SP6 primer (ATTTAGGTGACACTATA) and the 3 '-XbaI primer
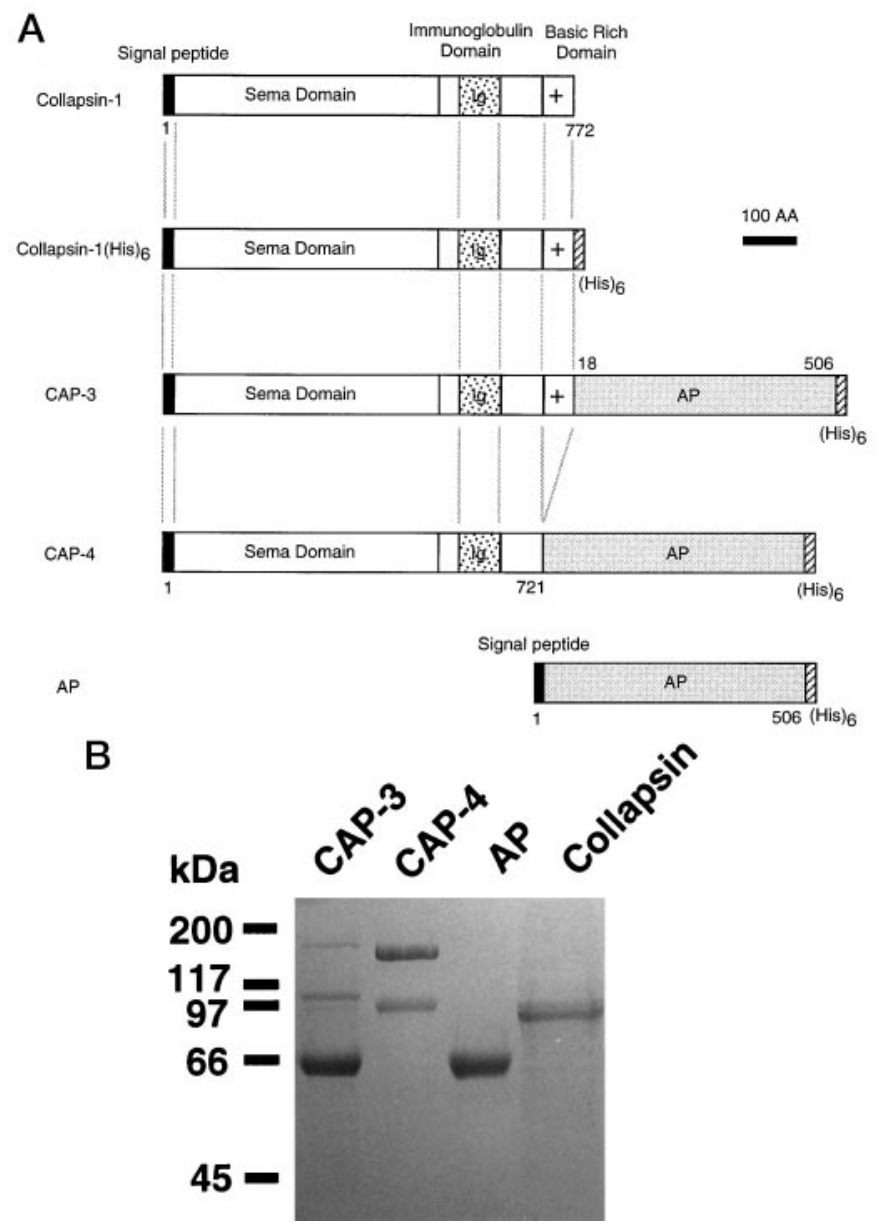

Figure 1. Purification of a collapsin-1-alkaline phosphatase fusion protein. $A$, Schematic illustrating the structure of recombinant proteins. Because a full-length collapsin-1-alkaline phosphatase fusion protein $(C A P-3)$ was degraded in the basic rich region at the $\mathrm{C}$ terminal of collapsin-1, a truncated form of collapsin-1 lacking the basic rich region at the $\mathrm{C}$ terminal was fused with alkaline phosphatase $(C A P-4)$. B, SDS PAGE of purified recombinant proteins. Fusion protein preparations (2 $\mu \mathrm{g}$ ) were analyzed by $10 \%$ SDS-PAGE. The $C A P-3$ preparation contains a significant fraction of degraded $66 \mathrm{kDa}$ protein similar in molecular weight to alkaline phosphatase $(A P)$ and a second degraded protein species of $110 \mathrm{kDa}$. Only a minor portion of the $C A P-3$ is full-length 165 $\mathrm{kDa}$ fusion protein. Although the $C A P-4$ preparation contains a minor amount of degraded $97 \mathrm{kDa}$ protein, the majority of protein is full-length $160 \mathrm{kDa}$ fusion protein. Collapsin-1-His ${ }_{6}$ exhibits the expected full-length $95 \mathrm{kDa}$ size.

(GATTCTAGAATCCATCGTGTTCAGGTTGGGGTG), digested with $H i n \mathrm{dIII}$ and $X b a \mathrm{I}$, and inserted into HindIII-XbaI sites of pcAP3 to create sema D-AP. The extracellular domain of semaphorin F (-7-1986) was amplified by PCR from pBluescript SK-semaphorin F (Inagaki et al., 1995) with the 5'-EcoRI primer (GATGAATTCTCTGCCATGGCCCCACACTGGGCTGTC) and the $3^{\prime}$-XbaI primer (GATTCTAGAGTTTTCCAAGGGAGCCCGTGCCTC), digested with Eco RI and XbaI, and ligated into EcoRI-XbaI sites of pcAP3 to create M-sema F-AP. The ligation sites of all constructs were confirmed by DNA sequencing.

Expression and purification of recombinant proteins. Twenty to thirty micrograms of purified expression vector DNA were transfected into $1.5 \times 10^{7}$ HEK293T cells by the calcium-phosphate method. Conditioned medium was collected 3-5 d after transfection. Conditioned medium from cells transfected with pcCAP- 4 exhibited $\sim 1$ U of AP activity per $\mathrm{ml}$, and medium from pcAP-transfected cells yielded $10 \mathrm{U}$ of AP activity per ml. One unit of AP activity is defined as $1 \mu \mathrm{mol}$ of $p$ nitrophenyl phosphate hydrolyzed $/ \mathrm{min}$ at $37^{\circ} \mathrm{C}$ (Flanagan and Leder, 1990). 

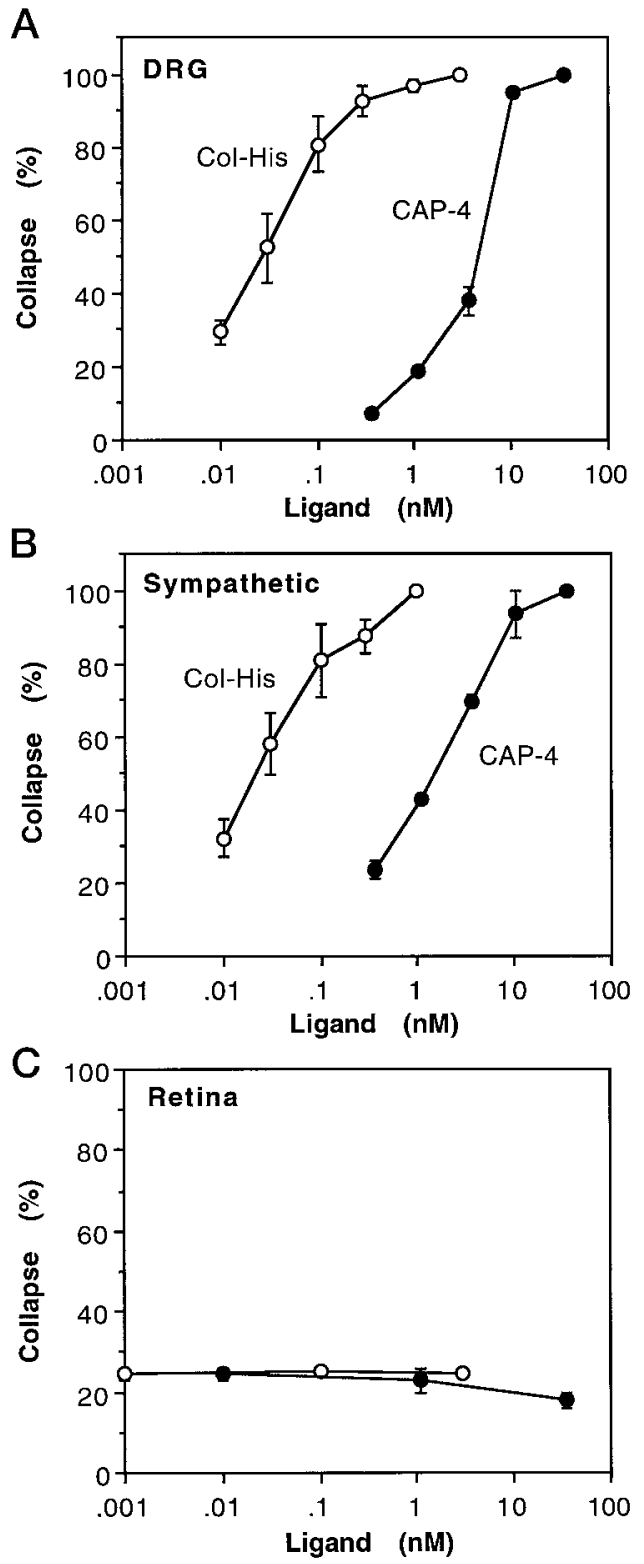

Figure 2. Growth cone collapse activity of collapsin-1-His ${ }_{6}$ and CAP-4. Growth cone collapse of chick E7 DRG explants $(A)$, dissociated chick E7 sympathetic neurons $(B)$, and chick E7 retinal explants $(C)$ was determined with various concentrations of $C A P-4$ (closed circle) and collapsin$1-\mathrm{His}_{6}\left(\mathrm{Col}-\mathrm{His}\right.$; open circle) as indicated. The $\mathrm{EC}_{50}$ values of collapsin$1-\mathrm{His}_{6}$ and CAP-4 are $50 \mathrm{pm}$ and $5 \mathrm{~nm}$, respectively, for both DRG and sympathetic neurons. The SEM from three to five determinations is shown.

To purify recombinant proteins, we supplemented $200 \mathrm{ml}$ of medium to $50 \mathrm{~mm}$ imidazole- $\mathrm{HCl}, \mathrm{pH} 7.3$, and $0.5 \mathrm{M} \mathrm{NaCl}$ and then passed the medium through a $0.45 \mu \mathrm{m}$ filter (AP-His ${ }_{6}, \mathrm{CAP}-3$, CAP-4, sema B, sema $\mathrm{D}$, and M-sema F) or centrif uged it at $100,000 \times g$ for 90 min at $4^{\circ} \mathrm{C}$ (collapsin- $\left.\mathrm{His}_{6}\right)$. The ultracentrifuge supernatant or the filtrate was applied to a $0.75 \mathrm{ml} \mathrm{Ni-containing} \mathrm{resin} \mathrm{(Probond;} \mathrm{Invitrogen).} \mathrm{The}$ column was washed with $5 \mathrm{ml}$ of $50 \mathrm{~mm}$ imidazole, $\mathrm{pH} 7.3$, and $0.5 \mathrm{M}$ $\mathrm{NaCl}$ and then eluted with a stepwise gradient of imidazole buffer in 0.5 $\mathrm{M} \mathrm{NaCl}$. AP activity eluted primarily in the $200 \mathrm{~mm}$ imidazole fraction. The purified protein was frozen in liquid nitrogen and stored at $-80^{\circ} \mathrm{C}$. The small fraction of protein that aggregated during storage was removed by centrifugation at $15,000 \mathrm{rpm}$ in a microf uge for $15 \mathrm{~min}$ at $4^{\circ} \mathrm{C}$ before the staining protocols.

Neuronal cell culture and growth cone collapse assay. The preparation of
DRG, sympathetic ganglion, and retinal cultures from E7 chick embryos has been described previously (Igarashi et al., 1993; Strittmatter et al., 1994). The growth cone collapse assay has been described in detail (Raper and Kapfhammer, 1990; Strittmatter et al., 1994; Goshima et al., 1995). For selective culture of DRG subpopulations, E10 chick dissociated DRG cells were maintained in medium containing either NT-3 or $\mathrm{NGF}$ at $40 \mathrm{ng} / \mathrm{ml}$ for $48 \mathrm{hr}$ before CAP-4 staining.

Rat DRG, cortical plate, and brainstem neurons were obtained from E15 Sprague Dawley rat pups. After incubation in $0.05 \%$ trypsin EDTA for $15 \mathrm{~min}$ at $37^{\circ} \mathrm{C}$, tissues were dissociated in DMEM containing $10 \%$ FCS and $0.1 \mathrm{mg} / \mathrm{ml}$ DNase using a $1 \mathrm{ml}$ plastic micropipette tip. Dissociated cells were diluted in DMEM containing 10\% FCS, 2 mM Gln, 100 $\mathrm{IU} / \mathrm{ml}$ penicillin, and $100 \mu \mathrm{g} / \mathrm{ml}$ streptomycin. The medium used for DRG cultures was supplemented with $10 \mathrm{ng} / \mathrm{ml} \mathrm{NGF}$ and $10 \mathrm{ng} / \mathrm{ml} \mathrm{NT}-3$, and that for brainstem and cortical plate cells was supplemented with 0.5 $\mathrm{ng} / \mathrm{ml} \mathrm{BDNF}, 1 \mathrm{ng} / \mathrm{ml} \mathrm{NT}-4 / 5$, and $1 \mathrm{ng} / \mathrm{ml}$ NT-3. Recombinant human BDNF was generously provided by Cephalon (West Chester, PA) and NT-4/5 and NT-3 by Genentech (San Francisco, CA). Diluted cells were plated at a density of 125 cells $/ \mathrm{mm}^{2}$ on $14 \mathrm{~mm}$ round glass coverslips (Assistant), which had been precoated with $0.1 \mathrm{mg} / \mathrm{ml}$ poly-D-ornithine followed by $2 \mu \mathrm{g} / \mathrm{ml}$ mouse laminin.

Motoneurons from embryonic day 15 rat pups were purified as described previously (Camu and Henderson, 1992). This procedure uses differential centrifugation and immunopanning with anti-p75 NGF receptor antibodies to obtain highly enriched motoneuron cultures. The cells were seeded at 25 cells $/ \mathrm{mm}^{2}$ onto poly-D-ornithine- and lamininprecoated glass coverslips in L-15 medium supplemented with 0.63 $\mathrm{mg} / \mathrm{ml}$ sodium bicarbonate, $100 \mathrm{IU} / \mathrm{ml}$ penicillin, $100 \mu \mathrm{g} / \mathrm{ml}$ streptomycin, $2 \%$ horse serum, $20 \mathrm{~mm}$ glucose, $5 \mu \mathrm{g} / \mathrm{ml}$ insulin, $0.1 \mathrm{~mm}$ putrescine, $20 \mathrm{nM}$ progesterone, $0.1 \mathrm{mg} / \mathrm{ml}$ conalbumin, $30 \mathrm{~nm}$ sodium selenite, 0.5 $\mathrm{ng} / \mathrm{ml} \mathrm{BDNF}, 1 \mathrm{ng} / \mathrm{ml} \mathrm{NT}-4 / 5$, and $1 \mathrm{ng} / \mathrm{ml} \mathrm{NT}-3$.

Staining of cell cultures. After 24-72 hr of incubation, cell cultures were washed once with HBH (Hank's balanced salt buffer with $0.5 \mathrm{mg} / \mathrm{ml}$ BSA and $20 \mathrm{mM}$ HEPES, $\mathrm{pH}$ 7.0) and then blocked with DMEM containing $10 \% \mathrm{FCS}$ and $100 \mathrm{IU} / \mathrm{ml}$ penicillin and streptomycin for $15 \mathrm{~min}$ at $23^{\circ} \mathrm{C}$. The cultures were then incubated with various amounts of CAP-4 and collapsin-1-His ${ }_{6}$ in DMEM/FBS for $2 \mathrm{hr}$ at $10^{\circ} \mathrm{C}$ and washed with ice-cold $\mathrm{HBH}$ six times for $3 \mathrm{~min}$ each. Washed cells were fixed with $3.7 \%$ formaldehyde in $20 \mathrm{~mm}$ HEPES, pH 7.0, and $150 \mathrm{~mm} \mathrm{NaCl}$ for $15 \mathrm{~min}$, washed with HH (Hank's balanced salt buffer with $20 \mathrm{~mm}$ HEPES, pH 7.0) twice, and incubated in $\mathrm{HH}$ for $2 \mathrm{hr}$ at $65^{\circ} \mathrm{C}$ to inactivate the heat-labile endogenous alkaline phosphatases. Bound heat-stable alkaline phosphatase was detected by incubation with $p$-nitrophenyl phosphate or with nitroblue tetrazolium $(34 \mu \mathrm{g} / \mathrm{ml})$ and 5-bromo-4-chloro-3indolyl phosphate $(18 \mu \mathrm{g} / \mathrm{ml})$ in AP buffer (100 mM Tris-HCl, pH 9.5, $100 \mathrm{~mm} \mathrm{NaCl}$, and $5 \mathrm{~mm} \mathrm{MgCl}$ ) for $24 \mathrm{hr}$ at room temperature.

Some E10 DRG cultures were stained for trkC after CAP-4 staining. These samples were incubated with affinity-purified rabbit anti-trkC antibody $(1 \mu \mathrm{g} / \mathrm{ml})$ directed against residues $798-812$ of the porcine sequence (Santa Cruz Biotechnology, Tebu, France), and bound antibody was detected after incubation with fluorescein-labeled goat antirabbit IgG (10 $\mu \mathrm{g} / \mathrm{ml}$; Sigma, St. Louis, MO).

Staining of tissue sections. E5, E7, E9, and E12 chick embryos were frozen on dry ice, and $20 \mu \mathrm{m}$ sections were cut on a cryostat and thaw-mounted onto Superfrost ${ }^{+}$slides (Fisher Scientific, Houston, TX). Sections were fixed with $100 \%$ methanol at $-80^{\circ} \mathrm{C}$ for $10 \mathrm{~min}$. Fixed sections were rehydrated in PBS, equilibrated with $\mathrm{HBH}$ for $5 \mathrm{~min}$, and then preblocked with $\mathrm{HBH}$ containing $20 \%$ fetal bovine serum for $1 \mathrm{hr}$. After preblocking, sections were incubated for $2 \mathrm{hr}$ with AP fusion proteins diluted into HBH containing $20 \%$ fetal bovine serum. For competitive inhibition experiments, AP fusion protein and collapsin-1$\mathrm{His}_{6}$ were added. Sections were washed with $\mathrm{HBH}$ once for $5 \mathrm{~min}$, with Tris-buffered saline (20 mm Tris- $\mathrm{HCl}$ and $135 \mathrm{~mm} \mathrm{NaCl}, \mathrm{pH} 7.5$ ) three times for $5 \mathrm{~min}$ each, and with PBS for $5 \mathrm{~min}$ and then fixed with $3.7 \%$ formaldehyde in PBS for $15 \mathrm{~min}$. The fixed sections were incubated in PBS at $65^{\circ} \mathrm{C}$ for $50 \mathrm{~min}$ to inactivate heat-sensitive endogenous alkaline phosphatases. Specimens were then washed with AP buffer three times for $5 \mathrm{~min}$ each and developed with nitroblue tetrazolium $(34 \mu \mathrm{g} / \mathrm{ml})$ and 5-bromo-4-chloro-3-indolyl phosphate $(18 \mu \mathrm{g} / \mathrm{ml})$ in AP buffer for $24 \mathrm{hr}$ at $23^{\circ} \mathrm{C}$.

To section chick embryos without freezing, we fixed whole embryos with methanol for $3 \mathrm{hr}$, and $100-200 \mu \mathrm{m}$ sections were cut with a vibrating microtome. Sections were then air-dried onto slides and rehydrated in PBS. The staining procedure was as described for cryostat 
Figure 3. Saturable staining of chick E7 DRG neurons by CAP-4. Dissociated cultures of chick E7 DRG neurons were stained with $10 \mathrm{~nm}$ CAP-4 (top left), with $10 \mathrm{~nm}$ CAP-4 in the presence of 50 nM collapsin-1-His ${ }_{6}$ (top right), or with 10 nм human placental alkaline phosphatase (bottom right). CAP-4 stained a subpopulation of DRG neurons. The CAP-4 staining was abolished in the presence of excess collapsin-1--His 6 . Human placental alkaline phosphatase did not stain DRG neurons. The growth cones of methanol-fixed DRG neurons were stained with $10 \mathrm{nM}$ CAP-4 (bottom left). Scale bar: bottom left, $30 \mu \mathrm{m}$; right and top left, $65 \mu \mathrm{m}$.
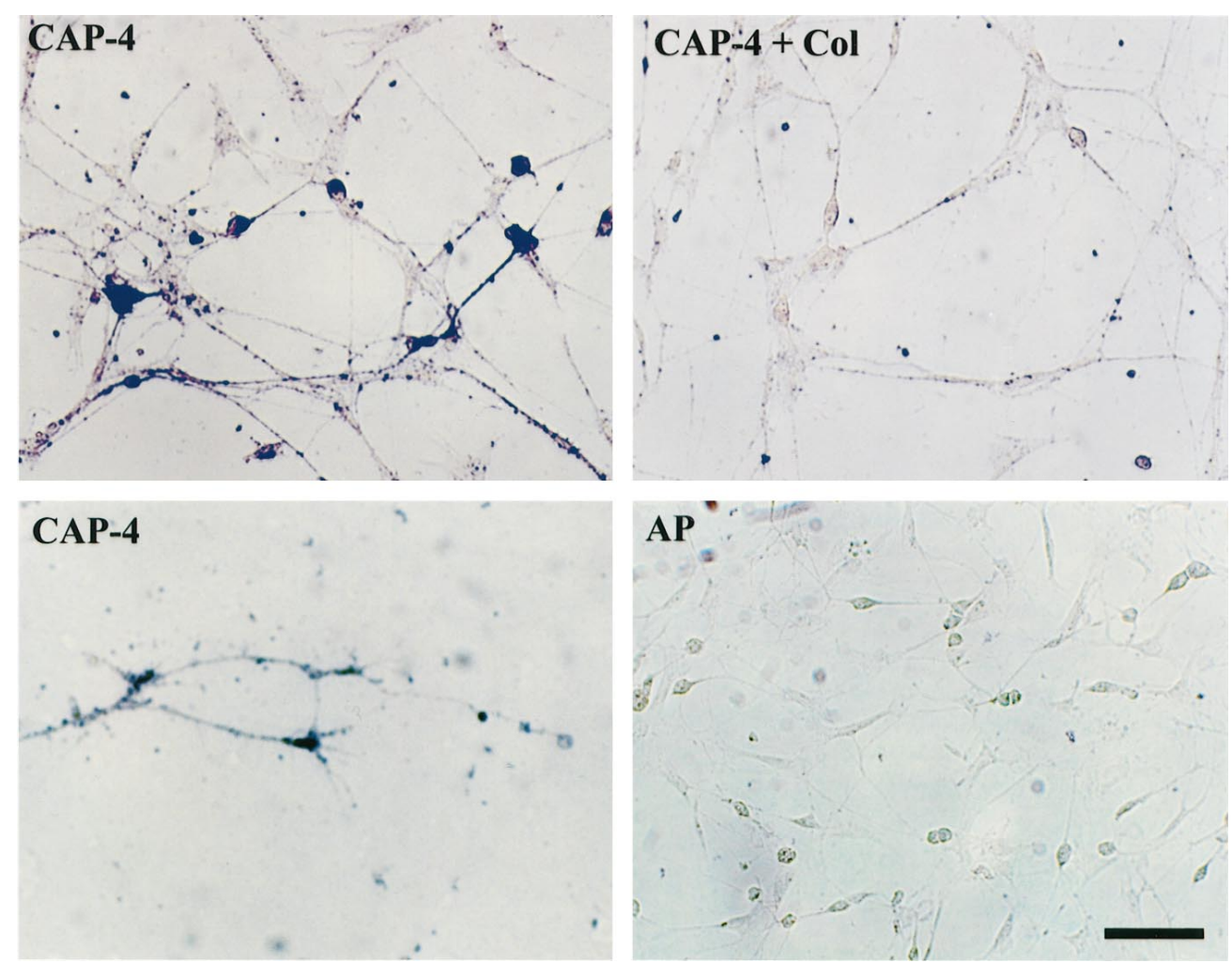

sections, except that sections were pretreated with buffer containing $1 \mathrm{M}$ $\mathrm{NaCl}$ and $0.1 \%$ Tween 20 to increase permeability.

\section{RESULTS}

\section{Isolation of biologically active collapsin-alkaline phosphatase fusion protein}

To visualize collapsin-1 receptors, we sought to develop a fusion protein consisting of collapsin- 1 and secreted placental alkaline phosphatase. This method has been used extensively to visualize the distribution of the SEK/MEK family of receptors and their ligands by Flanagan and colleagues (Chen and Flanagan, 1994; Chen et al., 1995; Nakamoto et al., 1996). Initial constructs consisted of collapsin-1 followed by alkaline phosphatase and a $\mathrm{His}_{6}$ tag (CAP-3). Purification of $\mathrm{His}_{6}$-tagged proteins from transfected HEK293T cells by nickel affinity chromatography demonstrated that the majority of $\mathrm{His}_{6}$-tagged fusion proteins were cleaved to a size nearly identical to that of alkaline phosphatase-His $_{6}$ (Fig. 1). There is a cluster of basic residues near the $\mathrm{C}$ terminal of the collapsin- 1 sequence that may be a site for endoproteolysis. To avoid this degradation, we deleted the last 52 residues of collapsin-1 from the fusion protein. The truncated collapsin-1 fusion protein (CAP-4) could be purified from transfected HEK293T cells with an apparent molecular size of 160 $\mathrm{kDa}$, as predicted for nonproteolyzed fusion protein (Fig. 1).

Purified recombinant collapsin-1-His 6 , and to a lesser degree CAP-4, aggregated when frozen at concentrations exceeding 1 $\mu \mathrm{g} / \mathrm{ml}$. Aggregation could be minimized by storing stock solutions with $>0.5 \mathrm{M} \mathrm{NaCl}$. The small fraction of aggregated protein in high salt could be removed by centrif ugation of the protein.

The truncation in CAP-4 removes only a small portion of the collapsin-1 sequence that is not in the highly conserved sema domain, suggesting that the CAP-4 protein is likely to retain biological activity. Collapsin-1 induces growth cone collapse in DRG and sympathetic neurons but not in axons of retinal gan- glion cells (Fig. 2). As expected, the alkaline phosphatase protein has no effect on growth cone morphology (data not shown). The CAP-4 protein induces growth cone collapse with a specificity indistinguishable from that of collapsin-1 and with an $\mathrm{EC}_{50}$ of $\sim 5$ nM, $\sim 100$-fold higher than that of collapsin-1-His ${ }_{6}$ (Fig. 2). Thus, CAP-4 provides a biologically active, labeled and purified ligand for collapsin-1 binding sites.

\section{High-affinity binding of CAP-4 to cultured neurons}

Neuronal cultures were incubated with CAP-4 to visualize collapsin-1 binding sites, and bound protein was visualized by alkaline phosphatase reaction (Fig. 3). Dense staining was observed in chick E7 DRG soma, neurites, and growth cones (Fig. 3 ). Although the intensity of staining varied between different DRG neurons in the culture, sympathetic neurons were uniformly and intensely stained (Fig. 3; see below). Non-neuronal cells were not stained in the mixed cultures. To demonstrate further the specificity of CAP-4 staining, we analyzed several control conditions. Alkaline phosphatase yielded no staining (Fig. 3), indicating that the staining was dependent on the collapsin moiety of the fusion protein. Heating of CAP- 4 at $65^{\circ} \mathrm{C}$ destroys growth cone collapse activity and abolishes staining of DRG neurons (data not shown). Most selectively, CAP-4 staining was prevented by the addition of excess collapsin-1-His 6 (Fig. 3).

Using an alkaline phosphatase substrate that produces a soluble product, we could quantitate the amount of CAP-4 bound to cultured neurons (Fig. 4). Specific CAP-4 binding to sympathetic neurons is saturable with a $K_{D}$ of $3.3 \mathrm{~nm}$. Collapsin-1-His ${ }_{6}$ inhibits CAP-4 binding with an apparent $K_{i}$ of 250 pM. The $K_{D}$ of CAP-4 and the $K_{i}$ of collapsin-1-His ${ }_{6}$ in this binding assay are very close to the potency of these proteins in the growth cone collapse assay (Fig. 2), indicating that the CAP-4 staining is likely to reflect a biologically relevant site leading to growth cone collapse. The slightly higher $K_{i}$ for collapsin-1-His ${ }_{6}$ in the binding assay as 

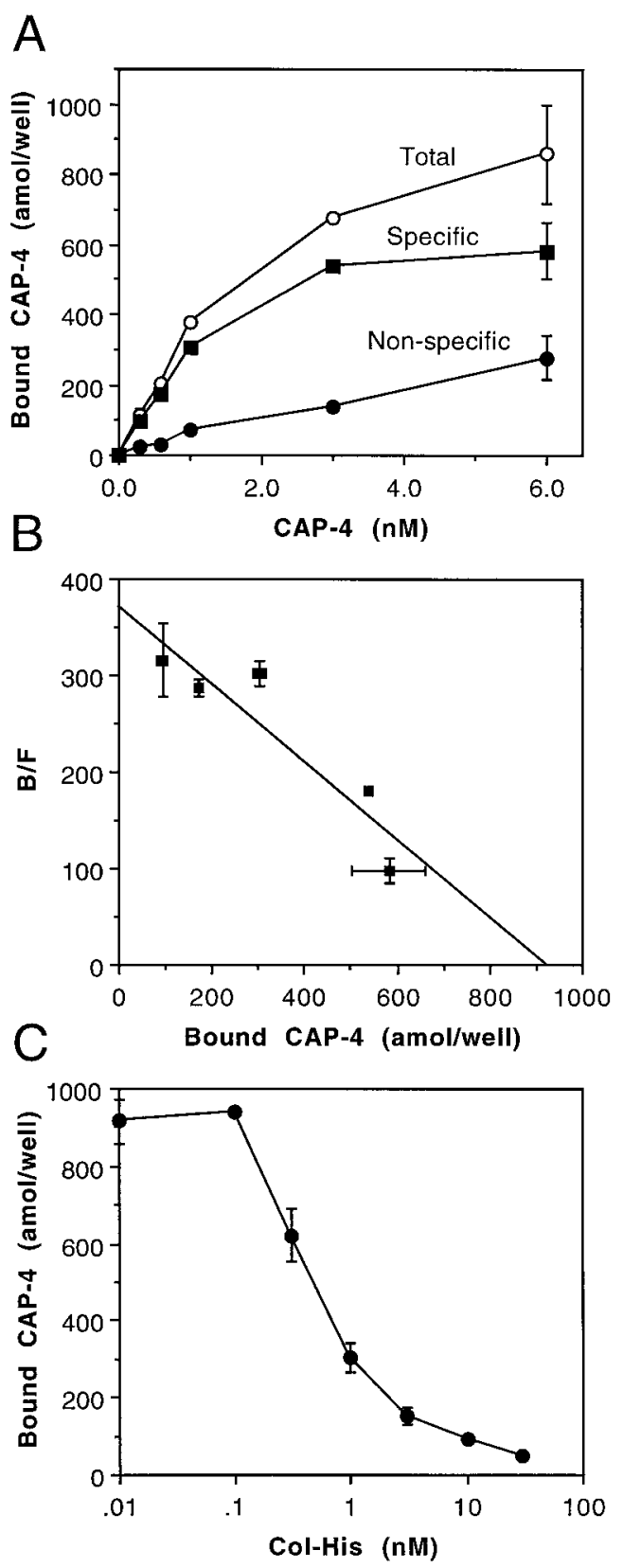

Figure 4. Quantitation of CAP-4 binding to chick sympathetic neurons. $A$, Saturation of CAP-4 binding to sympathetic neurons. Dissociated cultures of chick E7 sympathetic neurons were stained with various amount of CAP-4 (Total; open circle) or CAP-4 plus 100 nM collapsin-1$\mathrm{His}_{6}$ (Nonspecific; closed circle). Bound alkaline phosphatase activity was quantitated after the incubation with $p$-nitrophenyl phosphate by measuring the optical density at $415 \mathrm{~nm}$. Specific CAP-4 binding was calculated by subtracting nonspecific from total binding (Specific; square). B, Scatchard analysis of specific CAP-4 binding to sympathetic neurons. Scatchard analysis of specific CAP-4 binding from $A$ is shown. The calculated $K_{D}$ is $3.3 \mathrm{nM}$, and the $B_{\max }$ is $1 \mathrm{nmol}$ of CAP-4 bound per well. $C$, Inhibition of CAP-4 binding by collapsin- 1 . The binding of 4 nM CAP-4 to chick sympathetic neurons in the presence of the indicated concentrations of collapsin-1-His ${ }_{6}$ was quantitated as described in Materials and Methods. The $\mathrm{IC}_{50}$ is $500 \mathrm{pM}$, which corresponds to an apparent $K_{i}$ of $250 \mathrm{pm}$ assuming competitive inhibition and a $K_{D}$ for CAP-4 of $3.3 \mathrm{nM}$. Error bars indicate SEM for three to five determinations in $A-C$. opposed to its $\mathrm{EC}_{50}$ in the collapse assay may be because of the effects of longer incubation time and lower incubation temperature in the binding assay or because of the possibility that partial receptor occupancy induces growth cone collapse.

\section{Selectivity of CAP neuronal staining}

Only certain neuronal populations respond morphologically to collapsin-1 (Luo et al., 1993; Fig. 2). Neuronal populations known to be sensitive to the collapsing effects of collapsin-1 and semaphorin D/III include DRG neurons, sympathetic neurons, and motoneurons (Fig. 2; Luo et al., 1993; Shepherd et al., 1996). In contrast, retinal ganglion cell growth cones and cortical neurons are insensitive to collapsin-1 (Luo et al., 1993; Shepherd et al., 1996). Furthermore, collapsin-1 has no effect on the shape of kidney COS cells. CAP-4 stains sympathetic neurons and motoneurons specifically but not retinal neurons, brainstem neurons, cortical neurons, or COS cells (Fig. 5; data not shown). Sympathetic neurons are strongly and uniformly stained by CAP-4. The motoneuron-enriched culture prepared by differential centrif ugation and anti-p75 panning contains two populations of cells: a group with large cell bodies that are islet-1-positive, p75-positive, and L14-positive and a second set with smaller cell bodies that are islet-1-negative, p75-positive, and L14-positive (Henderson et al., 1993). Although the larger cells are clearly motoneurons, the identity of the smaller cells in these cultures is less clear. CAP-4 stains the majority of the large cells but few if any of the smaller cells. CAP-4 staining of these cells is most prominent within the soma region (Fig. 5), although at high magnification, staining of axons is also detectable. Overall, the selectivity of staining matches the morphological sensitivity of growth cones.

Two populations of DRG neurons with different collapsin-1 sensitivities have been documented (Messersmith et al., 1995; Shepherd et al., 1997). The NGF-dependent, trkC-negative, collapsin-1-sensitive pool projects dorsally in the spinal cord. In contrast, the NT-3-dependent, trkC-positive, collapsin-1insensitive pool of primary muscle afferents extends from the dorsal cord into the collapsin-1-expressing ventral spinal cord. If CAP-4 binds to physiologically relevant collapsin- 1 receptor sites, then CAP-4 staining should be selective for the first population. To examine this hypothesis, we cultured chick E10 neurons in NGF or in NT-3 to enrich for different subpopulations of neurons (Messersmith et al., 1995; Shepherd et al., 1997). CAP-4 staining is robust in the NGF-treated cultures and nearly absent in the NT-3-treated cultures (Fig. 6A). To confirm this selectivity, we also cultured E10 DRG cells with a mixture of NT-3 and NGF and then stained cells for both CAP-4 binding and immunoreactive trkC. A majority of CAP-4-binding-positive neurons are trkC-negative, whereas a majority of CAP-4-binding-negative neurons are trkC-positive (Fig. $6 B$ ). These data extend the coincidence of CAP-4 staining and physiological responsiveness to collapsin-1.

To localize high-affinity collapsin-1 binding sites in situ, we stained methanol-fixed cryostat and vibratome sections of chick embryos. In the E7 chick, transverse sections of the spinal cord demonstrate staining of motoneurons and DRG (Fig. 7). The dorsal half of the cord is relatively unstained. Motoneurons from cervical, thoracic, and lumbar spinal cord are stained with equal intensity. In the E4 and E5 chick, staining is less prominent, but the same general pattern is apparent (data not shown). By E12, CAP-4 staining of motoneurons is minimal, but axonal tracts in the ventral midline that are not labeled at E7 are prominently stained. This location corresponds to descending reticulospinal 

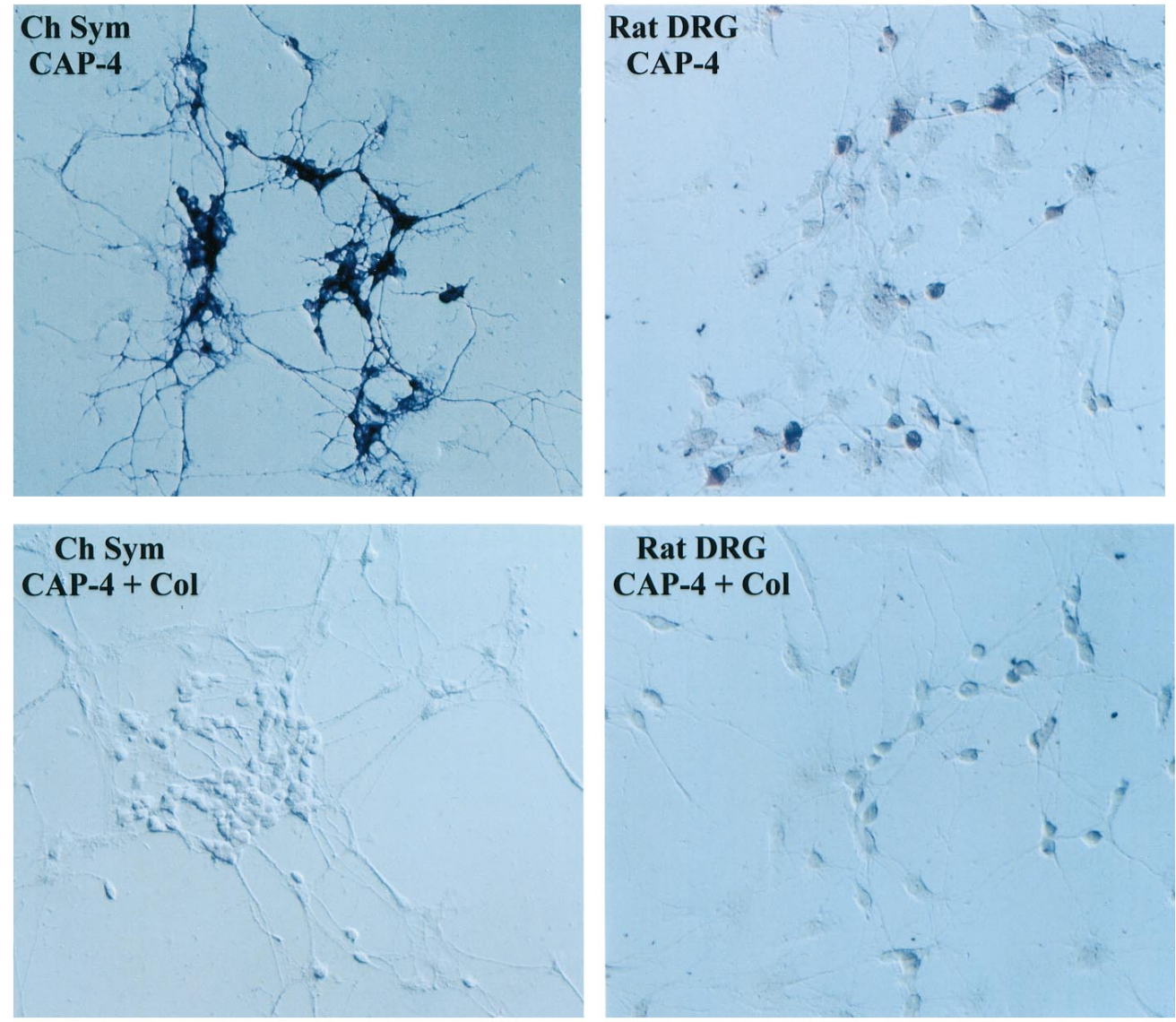

Figure 5. CAP staining of different neuronal populations. Chick E7 sympathetic neurons were stained with $10 \mathrm{~nm}$ CAP-4 (Ch Sym, CAP-4), and this staining was abolished in the presence of $50 \mathrm{~nm}$ collapsin-1-His 6 (Ch Sym, $C A P-4+C o l)$. Rat E15 DRG neurons were also stained with $10 \mathrm{~nm}$ CAP-4 (Rat DRG, CAP-4), and labeling was abolished by the addition of $50 \mathrm{~nm}$ collapsin-1-His ${ }_{6}$ (Rat DRG, CAP-4 + $\mathrm{Col}$ ). Although large diameter cells in rat E15 motoneuron-enriched cultures were stained with $10 \mathrm{nM} \mathrm{CAP-4} \mathrm{(Rat}$ $M N, C A P-4)$, rat cortical neurons (Rat Cortex, $C A P-4)$ and rat brainstem neurons (Rat BS, $C A P-4$ ) were not stained. Scale bar, $50 \mu \mathrm{m}$.
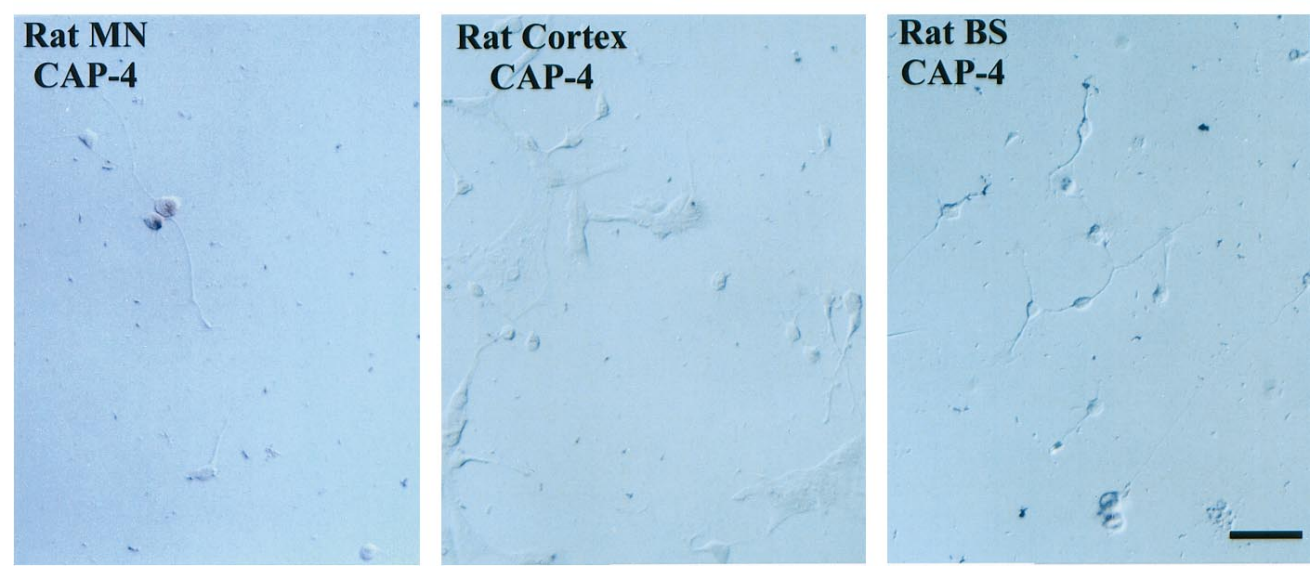

fibers, which also develop between E7 and E12 (Okado and Oppenheim, 1985). As seen for the staining of the primary neuronal cultures, all CAP-4 labeling in these sections is competitively inhibited by excess collapsin-1-His ${ }_{6}$. There is no detectable staining of retina or cerebral cortex at any of these ages (see Fig. $9 B$; data not shown).

\section{Localization of extraneuronal CAP-4 binding sites in developing chick}

CAP-4 staining is not found exclusively in neurons. Several extraneuronal tissues are prominently labeled in the E7 chick embryo. The highest level of staining is found in developing mesenchyme, especially surrounding bone and major blood vessels such as the aorta (Fig. 8). The density of staining in these areas exceeds that in motoneurons and DRG neurons. Specific CAP-4 staining of the aorta is found in the mesenchyme surrounding the aorta, but there is no labeling of the aorta (Fig. 8). High levels of staining are also present throughout the developing lung (Fig. 8). The mesenchyme surrounding a subset of developing bones is stained intensely (Fig. 8). The mesenchymal tissue immediately adjacent to the vertebral bodies between bone and dura exhibits the densest reaction product of any site in the developing chick (Fig. 7). Mesenchyme surrounding bone is also labeled by CAP-4 in the proximal segments of the wing bud (Fig. 8). Visceral organs including the heart, the liver, the kidney, and the intestine are essentially unstained (data not shown). The skin does not exhibit significant labeling.

\section{Staining by other semaphorin-alkaline phosphatase fusion proteins}

Collapsin-1 belongs to a large family of semaphorin proteins. Mouse semaphorin D/III is homologous to chick collapsin-1. The 


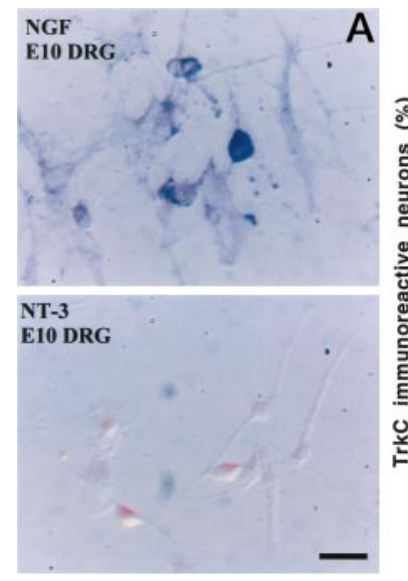

A

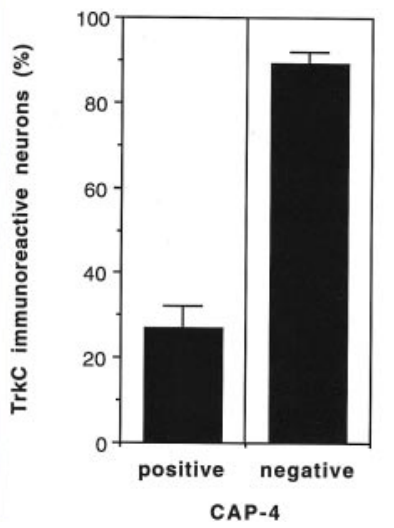

Figure 6. CAP-4 staining of E10 DRG neuronal subpopulations. $A$, Dissociated chick E10 DRG neurons were cultured in either NGF or NT-3 for $48 \mathrm{hr}$ and then stained with $3 \mathrm{nM} \mathrm{CAP-4}$ as described in Materials and Methods. Note the prominent staining of the NGFdependent neurons and the absence of staining of NT-3-dependent cells. Scale bar, $50 \mu \mathrm{m}$. B, Dissociated chick E10 DRG neurons were cultured in both NGF and NT-3 for $48 \mathrm{hr}$ and then stained with CAP-4 and anti-trkC antibody as described in Materials and Methods. The percentage of CAP-4-binding-positive neurons also exhibiting trkC immunoreactivity is low compared with the fraction of CAP-4-negative neurons that are trkC immunoreactive. The percentage of E10 DRG neurons stained by CAP- 4 was $50 \pm 2 \%$. The SEM from three separate experiments is shown.

amino acid sequence identity within the sema domain is $94 \%$. We considered whether binding sites for semaphorins are selective for certain members of this family. To test this, we expressed semaphorin $\mathrm{B}-, \mathrm{D}-$, and $\mathrm{M}-\mathrm{F}-$ alkaline phosphatase fusion proteins with a truncated structure analogous to CAP-4. Murine semaphorin B is more closely related to chick collapsin-4 (amino acid identity of sema domain, $45 \%$ ) than to chick collapsin-1, -2, -3 , or $-5(31-34 \%)$. Murine M-semaphorin F is also more closely related to chick collapsin-4 (amino acid identity of sema domain, $51 \%$ ) than to other known chick collapsins (38-41\%). It is unclear whether murine semaphorin B and M-F are homologs of collapsin-4 or homologs of as yet unidentified chick collapsins. Each of the semaphorin-AP fusion proteins could be highly purified from transfected-cell conditioned medium (Fig. 9A). Although semaphorin $\mathrm{B}$ and $\mathrm{M}-\mathrm{F}$ are transmembrane proteins (Inagaki et al., 1995; Püschel et al., 1995), the semaphorin B and M-F fusion proteins lack the transmembrane segment and are secreted into the culture medium.

The staining pattern exhibited by these semaphorin fusion proteins was compared with that of CAP-4. Sema D-AP staining is indistinguishable from CAP-4 labeling and can be blocked by excess collapsin-1-His ${ }_{6}$ (Fig. 9B; data not shown). Thus, ligands and receptors of the semaphorin family can react across the chick-mouse species barrier. In contrast, sema B-AP and Msema F-AP fusion proteins label different cell populations, and staining is not competitively inhibited by excess collapsin-1-His ${ }_{6}$. Sema B-AP and M-sema F-AP both stain retinal ganglion cells and the medial longitudinal fasciculus in the midline of the dorsal midbrain. These structures are not labeled with CAP-4 or sema D-AP. Neither sema B-AP nor M-sema F-AP bind to the periaortic mesenchyme that is strongly labeled by CAP-4 and sema D-AP (Fig. 9B).
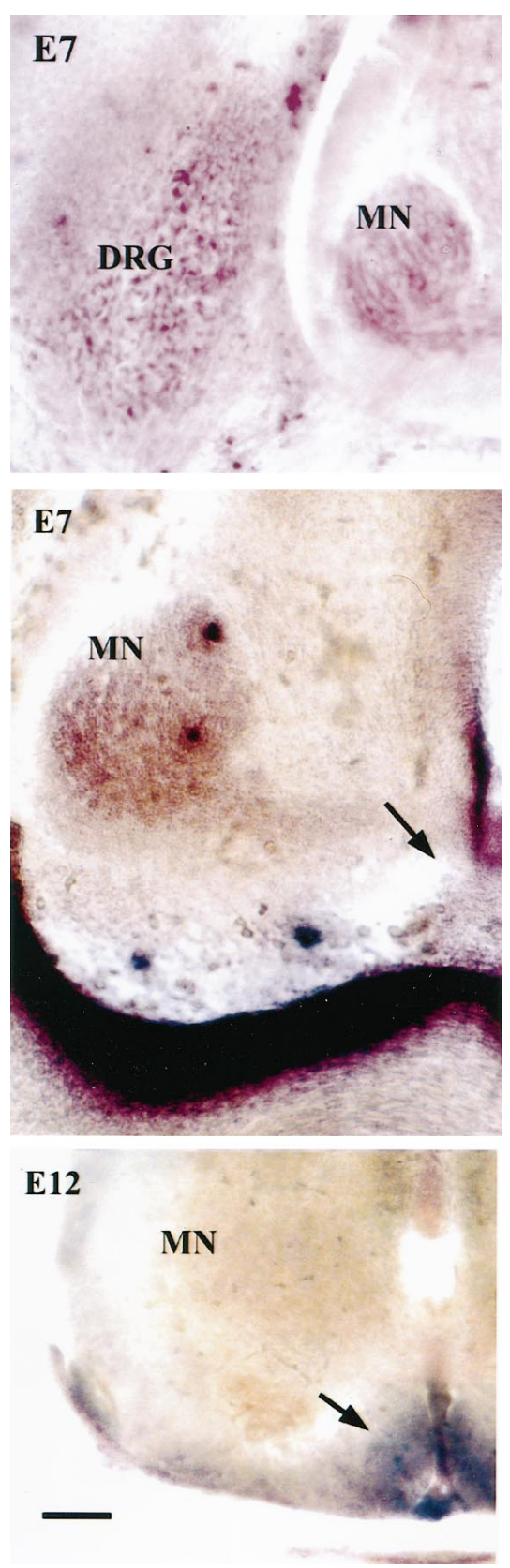

Figure 7. In situ localization of CAP-4 binding sites in developing chick nervous system. Transverse thoracic vibratome sections (dorsal surface at top) of chick E7 and E12 embryos were stained with 10 nM CAP-4. DRG and the motoneurons $(M N)$ of the ventral horn of the spinal cord were stained in E7 embryos (top panel). In E12 embryos, staining of the ventral horn was minimal, but the ventral midline of the spinal cord was stained (bottom panel; arrow). This ventral midline staining was not detectable in E7 specimens (middle panel; arrow). Staining of mesenchyme at the surface of the vertebral bodies was prominent in E7 preparations (middle panel). Scale bar: top and middle panels, $60 \mu \mathrm{m}$; bottom panel, $120 \mu \mathrm{m}$.

\section{DISCUSSION}

\section{Labeling of a candidate collapsin-1 receptor}

We have localized a CAP-4 binding site in developing chick tissues. There are three conceivable explanations for this CAP-4 binding site: (1) an artifact of the in vitro binding assay, (2) an "accessory" binding site that serves to localize soluble collapsin-1 by limiting its diffusion, and (3) a physiologically relevant recep- 
CAP-4

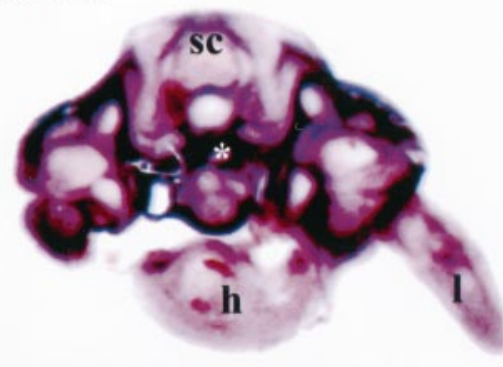

CAP-4 + Col-His

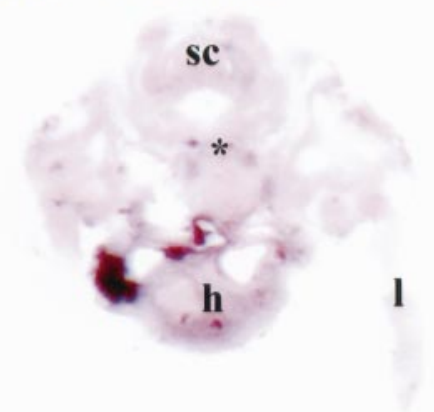

Figure 8. Localization of CAP-4 binding sites in extraneuronal sites. Transverse thoracic sections (dorsal surface at top) of the chick embryo were stained with $10 \mathrm{nM}$ CAP-4. Low magnification images of sections from E9 embryos reveal intense mesenchymal staining $(C A P-4)$ that is blocked by the addition of $50 \mathrm{~nm}$ collapsin-1-His 6 (CAP-4 + Col-His). The positions of the spinal cord $(s c)$, the aorta $(\star)$, the limb $(l)$, and the heart $(h)$ are indicated. The mesenchyme around the aorta was stained with 10 nм CAP-4 (Aorta, CAP-4) in the E9 chick embryo. This staining was blocked in the pres-

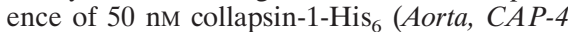
+ Col-His). The lung parenchyma was stained with 10 nM CAP-4 (Lung, CAP-4). The histological border of lung tissue is indicated by the asterisks. In the limb, the mesenchyme surrounding bone was stained with $10 \mathrm{~nm} \mathrm{CAP}-4$ (Limb, CAP-4). Scale bar: two top panels, 800 $\mu \mathrm{m}$; two bottom left panels, $100 \mu \mathrm{m}$; two bottom right panels, $200 \mu \mathrm{m}$.
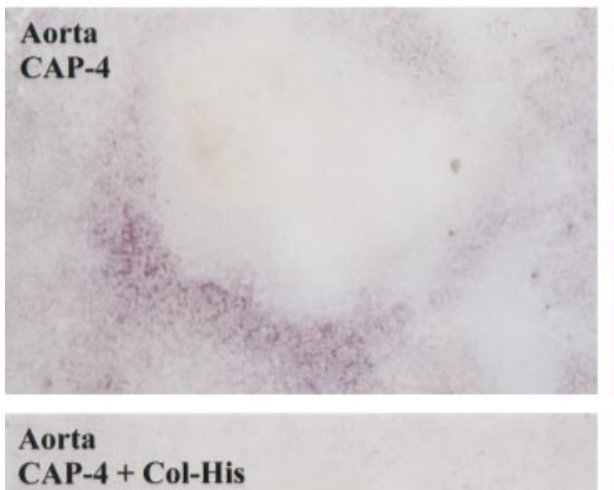

CAP-4 + Col-His

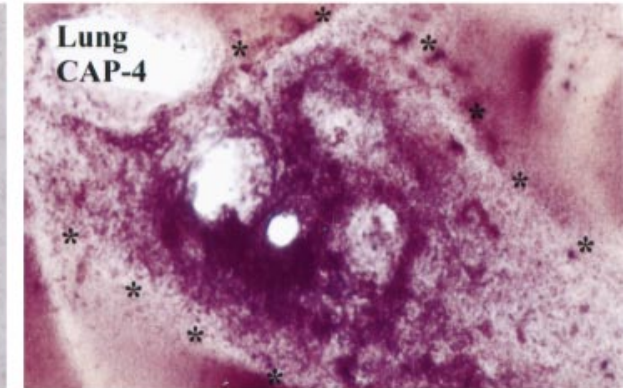

tor molecule. Several lines of evidence support the third view that CAP-4 labels a collapsin-1 binding site that mediates its inhibitory effects on growth cone motility. CAP-4 binding sites are saturable and of high affinity. The affinity of CAP-4 in the binding assay ( 3 $\mathrm{nM}$ ) is essentially identical to its $\mathrm{EC}_{50}$ in the growth cone collapse assay (5 nM). Likewise, the affinity of collapsin-1 in the CAP-4 binding assay (250 pM) is within an order of magnitude of its $\mathrm{EC}_{50}$ in the growth cone collapse assay (50 pM). Furthermore, CAP-4 stains the same neurons that are sensitive to collapsin-1-induced axon repulsion. It is unlikely that the $\mathrm{C}$-terminal truncation in CAP-4 unmasks a binding specificity distinct from that of intact collapsin-1 because the CAP-3 preparation, containing fulllength collapsin-1-AP and proteolytic N-terminal truncations, exhibits a staining pattern for cultured neurons and for tissue sections indistinguishable from that of CAP-4 (data not shown). Overall, the data favor the hypothesis that CAP-4 labels a physiologically relevant collapsin-1 receptor.

\section{Neuronal localization of collapsin-1 receptors}

CAP-4 binding sites are visualized on those neurons the axons of which are repulsed by collapsin- 1 and not on neurons insensitive to collapsin-1-mediated inhibition. Thus, the distribution of the binding sites can account for the selectivity of collapsin-1 effects. Binding sites in growth cones are positioned to mediate acute effects on growth cone structure. Binding sites in other segments of the neuron may reflect receptor protein undergoing synthesis and transport to the growth cone. Alternatively, the sites along the axon shaft may mediate the stimulatory effects of collapsin-1 on axonal transport (Goshima et al., 1997).

Cultured DRG neurons display heterogeneous CAP-4 binding. It has been suggested that those NT-3-dependent primary muscle afferent fibers that project to the semaphorin III-expressing ventral cord of the mouse are insensitive to semaphorin III and that this allows their projection to the correct location (Messersmith et al., 1995). In the chick, those DRG neurons expressing the highaffinity receptor for NT-3 (trkC) are insensitive to collapsin-1 at E10 (Shepherd et al., 1997). CAP-4 staining exhibits the same pattern of selectivity among E10 DRG neurons as does collapsin-1 sensitivity, with little labeling of the NT-3-dependent, trkC-positive subpopulation. Although DRG axon and growth cone staining is easily observed in cultured cells, DRG axonal projections to the dorsal spinal cord and periphery are below the detection limit in our tissue sections.

At all levels of the neuraxis, developing motoneurons are repulsed by semaphorin D/III (Varela-Echavarria et al., 1997). In tissue culture, purified rat E15 motoneurons are stained with CAP-4. CAP-4 binding to developing chick ventral spinal cord is easily visualized in tissue sections and corresponds to the location of motoneuron cell bodies.

Sympathetic neurons are also sensitive to collapsin-1 and stain with CAP-4. Presumably this contributes to the restriction of 


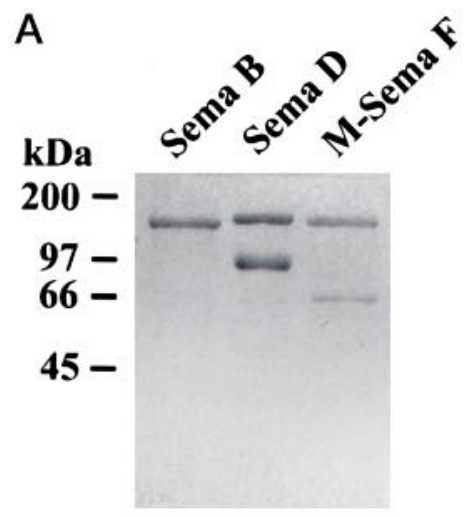

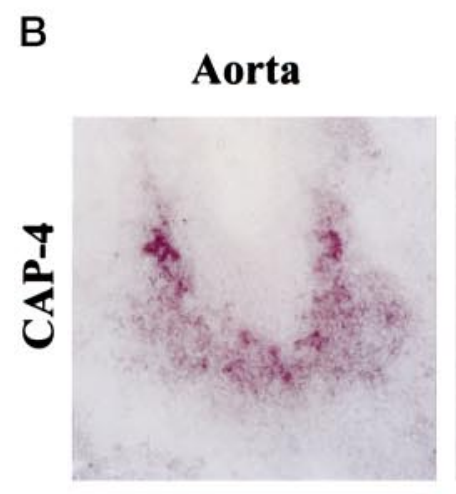

\section{Dorsal Midbrain}
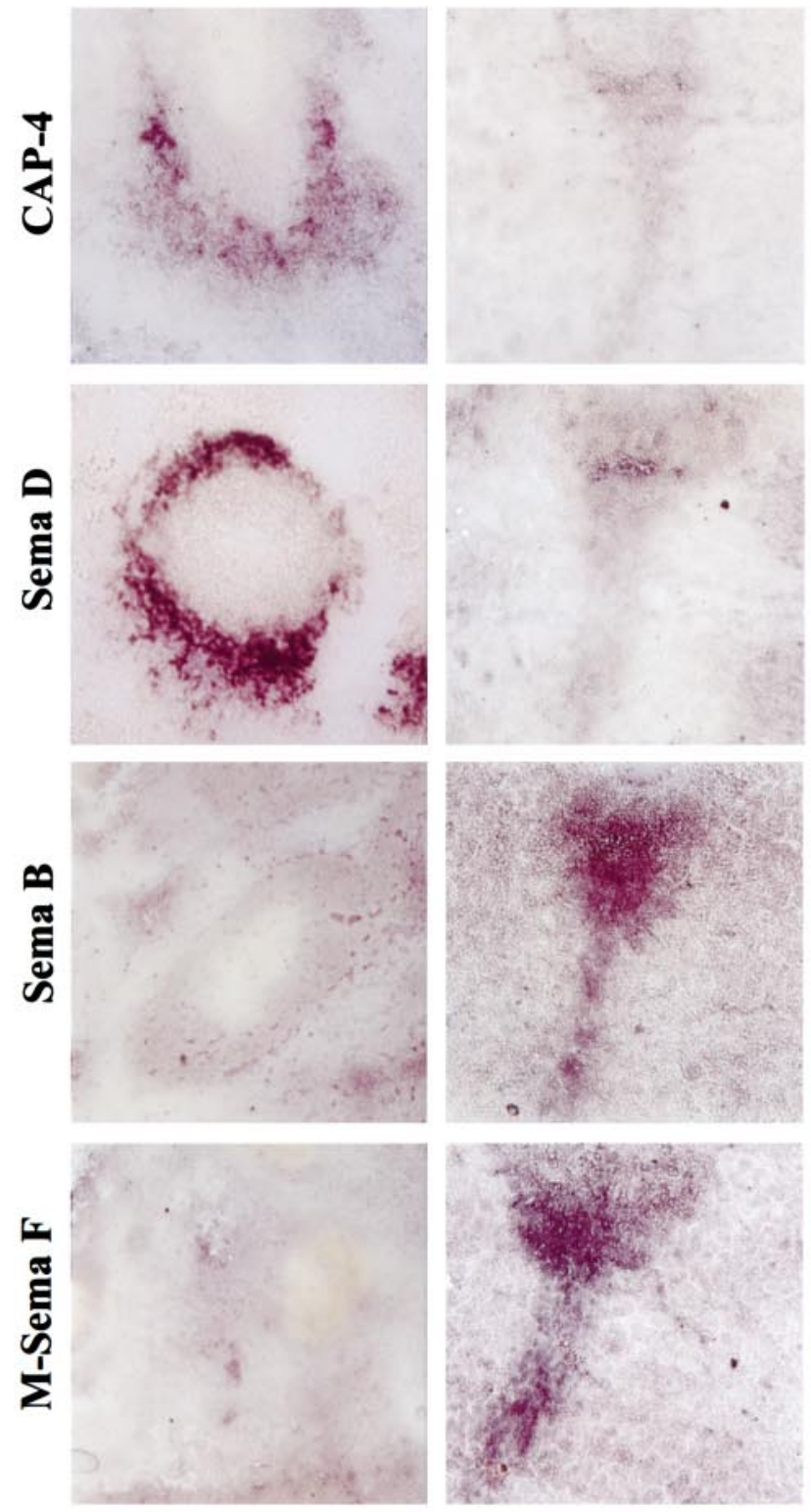

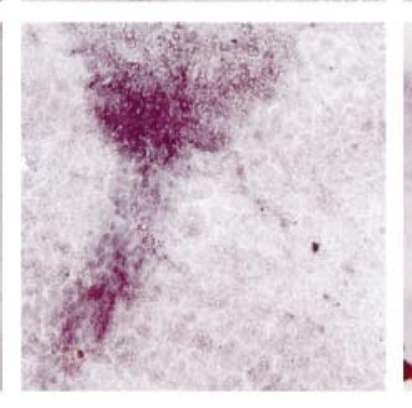

\section{Retina}
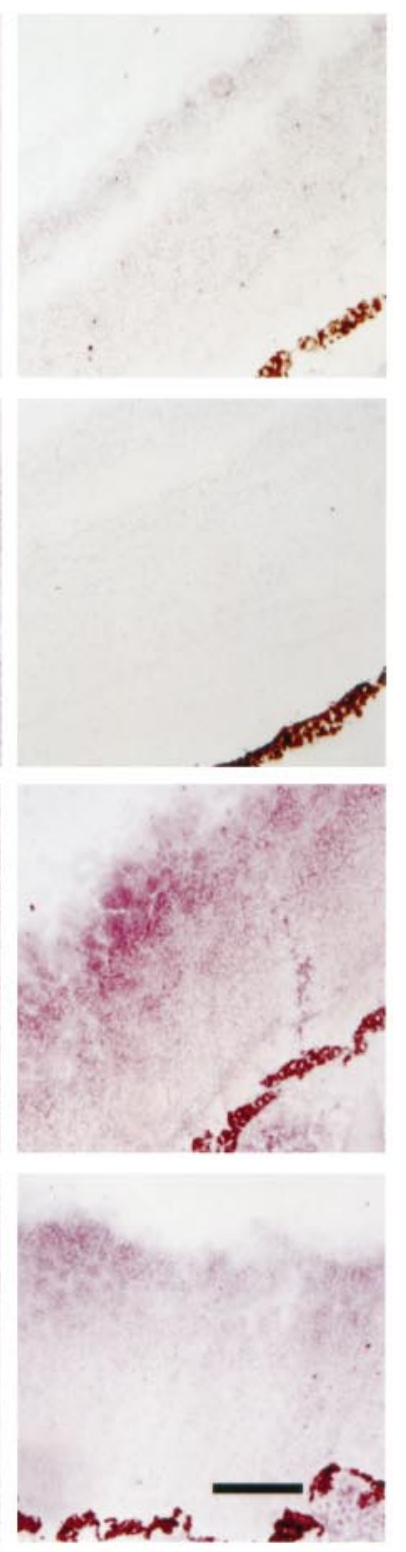

Figure 9. Differential localization of semaphorin binding sites. $A$, Purification of semaphorin B, D, and M-F fusion proteins. Fusion proteins $(2 \mu \mathrm{g})$ were analyzed by $10 \%$ SDSPAGE. Semaphorin B extracellular domain-alkaline phosphatase fusion protein (Sema B) is purified in its full-length form of $150 \mathrm{kDa}$. The truncated semaphorin D-alkaline phosphatase fusion protein preparation (Sema D) contains the predicted protein of $165 \mathrm{kDa}$ and a degraded protein of $97 \mathrm{kDa}$. The M-semaphorin F extracellular domain-alkaline phosphatase fusion protein $(M$-Sema $F)$ preparation exhibits protein staining at the predicted size of $150 \mathrm{kDa}$ and a minor fraction of a degraded protein at $66 \mathrm{kDa}$. $B$, Localization of semaphorin-alkaline phosphatase binding sites. Cryostat sections of E9 chick embryo were stained with $C A P-4$, Sema $B-A P$, Sema $D-A P$ and $M$-Sema $F-A P(10 \mathrm{nM})$. Although $C A P-4$ and Sema $D-A P$ stained the mesenchyme around the aorta in transverse thoracic sections, Sema $B-A P$ and $M$-Sema $F-A P$ did not. Coronal sections containing the midline of the dorsal midbrain and transverse sections of the nasal retina were stained by Sema $B-A P$ and $M$-Sema $F-A P$ but not by $C A P-4$ or Sema $D-A P$. The dorsal surface is at the top of each section. Scale bar, $100 \mu \mathrm{m}$. sympathetic innervation to certain regions of the embryo. The density of CAP-4 binding sites in sympathetic neurons is greater than that in DRG neurons or motoneurons, emphasizing the potential importance of semaphorin signaling in autonomic nervous system formation.

At E12, CAP-4 labels axonal tracts in the ventral midline. The 
spatial and temporal development of CAP-4 binding sites in this location is similar to that of the reticulospinal tract (Okado and Oppenheim, 1985). This suggests that collapsin-1 signaling may contribute to the establishment of some descending pathways in the spinal cord.

\section{Non-neuronal functions for collapsin-1}

Several extraneuronal sites are intensely and specifically stained with CAP-4. This finding implies that collapsin-1 might participate in pattern formation for tissues other than the nervous system. The high level expression of collapsin-1 and semaphorin D/III mRNA in the mesenchyme surrounding bone (Wright et al., 1995; Giger et al., 1996; Shepherd et al., 1997) is matched with high level CAP-4 staining in this location. For both collapsin-1 and CAP-4 binding sites, this mesenchymal tissue exhibits the highest expression levels. Thus, a local semaphorin ligand-receptor interaction may contribute to bone patterning. These CAP-4 binding sites provide a molecular substrate for the rib duplication and other abnormalities of bone development that occur in sema III $(-/-)$ mice (Behar et al., 1996). This hypothesis contrasts with the view that high mesenchymal collapsin-1 expression in mesenchymal structures functions primarily to exclude extending axons from certain areas of the embryo (Wright et al., 1995; Giger et al., 1996; Shepherd et al., 1997). It is possible that both functions are served by mesenchymal collapsin-1 expression during development.

The lung also coexpresses CAP-4 binding sites (Fig. 8) and semaphorin D/III mRNA (Giger et al., 1996). Thus, collapsin-1 signaling may contribute to the formation of lung architecture, and disruption of collapsin-1 signaling in the lungs of sema III $(-/-)$ mice may cause the hypertrophy of the right ventricle of the heart (Behar et al., 1996). The high levels of CAP-4 staining in the mesenchyme surrounding the aorta is diffuse and does not seem to be caused by neuronal fiber ingrowth. Staining in this area does not colocalize with the neuronal markers such as neurofilament (T. Takahashi and S. M. Strittmatter, unpublished observations). It is possible that collapsin-1 and semaphorin D/III may participate in the development of the vascular architecture. If so, this might provide an alternative explanation for the right ventricle hypertrophy observed in sema III (-/-) mice.

How might collapsin-1 binding sites function in these developing non-neuronal tissues? Collapsin-1 can regulate the motility of the growth cone via the actin-modulating small GTP binding protein rac1 (Jin and Strittmatter, 1997). Conceivably, mesenchymal development might be determined in part by collapsin-1 regulation of the same rac1-actin pathway in non-neuronal cells. Although CRMP seems to mediate collapsin-1-induced growth cone collapse (Goshima et al., 1995), its expression is neuralspecific (Wang and Strittmatter, 1996), unlike rac1. Therefore, any collapsin-1 effects in non-neural tissues must use a distinct CRMP-independent signaling pathway.

Some regions of the embryo such as the retina and the skin exhibit collapsin-1 and semaphorin D/III mRNA expression (Wright et al., 1995; Giger et al., 1996; Shepherd et al., 1996) but no CAP-4 binding. The function of collapsin-1 in these locations is unclear. It is possible that collapsin- 1 functions to exclude certain growing axons or migrating cells from these regions. Several organs including the liver, kidney, and heart express undetectable levels of both CAP-4 binding sites and semaphorin D/III mRNA. These organs are unlikely to use collapsin-1 directly during developmental morphogenesis.

\section{A family of semaphorin receptors}

Although semaphorin D/III and collapsin-1 seem to be homologous proteins binding to identical sites in the chick embryo, semaphorin $\mathrm{B}$ and $\mathrm{M}-\mathrm{F}$ interact with a different set of binding sites in the developing chick. Furthermore, staining by sema $\mathrm{B}-\mathrm{AP}$ and M-sema F-AP is not competitively inhibited by collapsin-1. The distribution of these binding sites may reflect the localization of a receptor for collapsin- 4 or for as yet unidentified chick collapsins. Regardless of the natural ligand for these sites, the data provide further proof of CAP-4 specificity for collapsin-1 receptors. The findings also imply that there is a family of semaphorin receptors, with a diversity equal to that of the semaphorin ligand family. The preliminary data suggest that sema B and M-sema F might contribute to axonal guidance in the medial longitudinal fasciculus and in the projection of retinal ganglion cells.

The demonstration of CAP-4 as a sensitive, high-affinity ligand for collapsin-1 binding sites is likely to be of great value in the ongoing isolation and characterization of the semaphorin receptor family.

\section{REFERENCES}

Behar O, Golden JA, Mashimo H, Schoen FJ, Fishman MC (1996) Semaphorin III is needed for normal patterning and growth of nerves, bones and heart. Nature 383:525-528.

Byk T, Dobransky T, Cifuentes-Diaz C, Sobel A (1996) Identification and molecular characterization of unc-33-like phosphoprotein (Ulip), a putative mammalian homologue of the axonal guidance-associated unc-33 gene product. J Neurosci 16:688-701.

Camu W, Henderson CE (1992) Purification of embryonic rat motoneuron by panning on a monoclonal antibody to the low-affinity NGF receptor. J Neurosci Methods 44:59-70.

Chen H-J, Flanagan JG (1994) Identification and cloning of ELF-1, a developmentally expressed ligand for the Mek-4 and Sek receptor tyrosine kinases. Cell 79:157-168.

Chen H-J, Nakamoto M, Bergemann AD, Flanagan JG (1995) Complementary gradients in expression and binding of ELF-1 and Mek4 in development of the topographic retinotectal projection map. Cell 82:371-381.

Dodd J, Schuchardt A (1995) Axon guidance: a compelling case for repelling growth cones. Cell 81:471-474.

Fan J, Mansfield SG, Redmond T, Gordon-Weeks PR, Raper JA (1993) The organization of F-actin and microtubules in growth cones exposed to a brain-derived collapsing factor. J Cell Biol 121:867-878.

Flanagan JG, Leder P (1990) The kit ligand: a cell surface molecule altered in steel mutant fibroblasts. Cell 63:185-194.

Furuyama T, Inagaki S, Kosugi A, Noda S, Saitoh S, Ogata M, Iwahashi Y, Miyazaki N, Hamaoka T, Tohyama M (1996) Identification of a novel transmembrane semaphorin expressed on lymphocytes. J Biol Chem 271:33376-33381.

Giger RJ, Wolfer DP, De Wit GMJ, Verhaagen J (1996) Anatomy of rat semaphorin III/collapsin-1 mRNA expression and relationship to developing nerve tracts during neuroembryogenesis. J Comp Neurol 375:378-392.

Goshima Y, Nakamura F, Strittmatter P, Strittmatter SM (1995) Collapsin-induced growth cone collapse mediated by an intracellular protein related to unc-33. Nature 376:509-514.

Goshima Y, Kawakami T, Sugiyama Y, Hashimoto Y, Hori H, Takanaka T, Misu Y, Strittmatter SM (1997) A novel action of collapsin: collapsin-1 increases antero- and retrograde axoplasmic transport independently of growth cone collapse. J Neurobiol 33:316-328.

Hall KT, Boumsell L, Schultze JL, Boussiotis VA, Dorfman DM, Cardoso AA, Bensussan A, Nadler LM, Freeman GJ (1996) Human CD100, a novel leukocyte semaphorin that promotes B-cell aggregation and differentiation. Proc Natl Acad Sci USA 93:11780-11785.

Henderson CE, Camu W, Mettling C, Gouin A, Poulse K, Kaihloo M, Rullamas J, Evans T, McMahon SB, Armanini MP, Berkemeir L, Phillips HS, Rosenthal A (1993) Neurotrophins promote motor neuron survival and are present in the embryonic limb bud. Nature 363:266-270. 
Herold C, Elhabazi A, Bismuth G, Benussan A, Boumsell L (1996) CD100 is associated with CD45 at the surface of human T lymphocytes. J Immunol 157:5262-5268.

Igarashi M, Strittmatter SM, Vartanian T, Fishman MC (1993) Mediation by $\mathrm{G}$ proteins of signals that cause collapse of growth cones. Science 259:77-79.

Inagaki S, Furuyama T, Iwahashi Y (1995) Identification of a member of mouse semaphorin family. FEBS Lett 370:269-272.

Jin Z, Strittmatter SM (1997) Rac1 mediates collapsin-1-induced growth cone collapse. J Neurosci 17:6256-6263.

Keynes R, Cook GMW (1995) Axon guidance molecules. Cell 83:161-169.

Kolodkin AL (1996) Semaphorins: mediators of repulsive growth cone guidance. Trends Cell Biol 6:15-22.

Kolodkin AL, Matthes DJ, O'Connor TP, Patel NH, Admon A, Bently D, Goodman CS (1992) Fasciclin IV: sequence, expression, and function during growth cone guidance in the grasshopper embryo. Neuron 9:831-845.

Kolodkin AL, Matthes DJ, Goodman CS (1993) The semaphorin genes encode a family of transmembrane and secreted growth cone guidance molecules. Cell 75:1389-1399.

Luo Y, Raible D, Raper JA (1993) Collapsin: a protein in brain that induces the collapse and paralysis of neuronal growth cones. Cell 75:217-227.

Luo Y, Shepherd I, Li J, Renzi MJ, Chang S, Raper JA (1995) A family of molecules related to collapsin in the embryonic chick nervous system. Neuron 14:1131-1140.

Matthes DJ, Sink H, Kolodkin AL, Goodman CS (1995) Semaphorin II can function as a selective inhibitor of specific synapse arborizations. Cell 81:631-639.

Messersmith EK, Leonardo ED, Shatz CJ, Tessier-Lavigne M, Goodman CS, Kolodkin AL (1995) Semaphorin III can function as a selective chemorepellent to pattern sensory projections in the spinal cord. Neuron 14:949-959.

Minturn JE, Fryer HJL, Geschwind DH, Hockfield S (1995) TOAD-64, a gene expressed early in neuronal differentiation in the rat, is related to unc-33, a C. elegans gene involved in axon outgrowth. J Neurosci 15:6757-6766.

Nakamoto M, Cheng H-J, Friedman GC, Maclaughlin T, Hansen MJ, Yoon CH, O'Leary DDM, Flanagan JG (1996) Topographically specific effects of ELF-1 on retinal axon guidance in vitro and retinal axon mapping in vivo. Cell 86:755-766.

Okado N, Oppenheim RW (1985) The onset and development of de- scending pathways to spinal cord in the chick embryo. J Comp Neurol 232:143-161.

Püschel AW (1996) The semaphorins: a family of axonal guidance molecules? Eur J Neurosci 8:1317-1321.

Püschel AW, Adams RH, Betz H (1995) Murine semaphorin D/collapsin is a member of a diverse gene family and creates domains inhibitory for axonal extension. Neuron 14:941-948.

Raper JA, Kapfhammer P (1990) The enrichment of a neuronal growth cone collapsing activity from embryonic chick brain. Neuron 2:21-29.

Roche J, Boldog F, Robinson M, Varella-Garcia M, Swanson M, Waggoner B, Fishel R, Franklin W, Gemmill R, Drabkin H (1996) Distinct 3 p21.3 deletions in lung cancer and identification of a new human semaphorin. Oncogene 12:1289-1297.

Sekido Y, Bader S, Latif F, Chen J-Y, Duh F-M, Wei M-H, Albanesi JP, Lee C-C, Lerman MI, Minna JD (1996) Human semaphorins A(V) and IV reside in the 3p21.3 small cell lung cancer deletion region and demonstrate distinct expression patterns. Proc Natl Acad Sci USA 93:4120-4125.

Shepherd I, Luo Y, Raper JA, Chang S (1996) The distribution of collapsin-1 mRNA in the developing chick nervous system. Dev Biol 173:185-199.

Shepherd I, Luo Y, Lefcort F, Reichardt LF, Raper JA (1997) A sensory axon repellent secreted from ventral spinal cord explant is neutralized by antibodies raised against collapsin-1. Development 124:1377-1385.

Strittmatter SM, Igarashi M, Fishman MC (1994) GAP-43 peptides modulate growth cone morphology and neurite outgrowth. J Neurosci 14:5501-5513.

Tessier-Lavigne M, Goodman CS (1996) The molecular biology of axon guidance. Science 274:1123-1133.

Varela-Echavarria A, Tucker A, Püschel AW, Guthrie S (1997) Motor axon subpopulations respond differentially to chemorepellents netrin-1 and semaphorin D. Neuron 18:193-207.

Wang LH, Strittmatter SM (1996) A family of rat CRMP genes is differentially expressed in the nervous system. J Neurosci 16:6197-6207.

Wright DE, White FA, Gerfen RW, Silos-Santiago I, Snider WD (1995) The guidance molecule semaphorin III is expressed in regions of spinal cord and periphery avoided by growing sensory axons. J Comp Neurol 361:321-333.

Xiang R-H, Hensel CH, Garcia DK, Carlson HC, Kok K, Daly MC, Kerbacher K, Berg AVD, Veldhuis P, Buys CHCM, Naylor SL (1996) Isolation of the human semaphorin III/F gene (SEMA3F) at chromosome 3p21.3, a region deleted in lung cancer. Genomics 32:39-48. 